DOI: $10.20472 / \mathrm{IAC} .2017 .33 .046$

RAJESH MOHNOT

Middlesex University, United Arab Emirates

\title{
EXAMINING GRANGER CAUSALITY IN THE BEHAVIORAL REACTIONS OF INSTITUTIONAL INVESTORS
}

\begin{abstract}
:
Institutional investors have played significant role in the growth and development of capital markets. Developed countries' capital markets have a proven record of success in terms of transforming funds from surplus units to deficit units. Both domestic institutional investors (DII) and foreign institutional investors (FII) have been instrumental in establishing key functional areas of stock markets and enhancing efficiency in the operations of such markets mechanisms. Domestic institutional investors try to facilitate funds availability in the core sectors of the economy; foreign institutional investors, on the other hand, provide funds to generate economic benefits from large scale projects like infrastructure. Both investor classes use stock markets to channel their funds for investment purposes and maximize their wealth.
\end{abstract}

Developed countries have seen institutional investors contributing significantly since 1960s but developing countries have been bit late mainly because of capital controls and other restrictive regulatory conditions. Foreign institutional investors have become active player in the developing countries from 1990 onwards when there was economic integration and financial liberalization process taking place especially in the developing part of the world. This has led the global institutional investors put approximately US\$63 trillion worth of assets under management by 2011 . Developing and emerging markets have also attracted vital share of the assets through institutional investing. Global investors found India as an attractive destination for investments and their net investments in Indian equities and debt amounted to US\$ 7.46 billion in 2016-17. Cumulatively, it makes up around US $\$ 183.69$ billion up to 2016. A recent report by Ernst \& Young suggests that India is rated $3 r d$ in the most attractive investment destinations in the world. But the growing activities of institutional investors have also raised some concerns about the behavioral reactions of the investors and their implications on the fundamental value of the stocks.

This paper is an attempt to examine those behavioral reactions of both institutional investors foreign and domestic. The study aims to apply granger causality on the institutional investments through vector autoregressive (VAR) model in order to find out relationship between foreign and domestic institutional investors trading strategies. It would also be interesting to see if foreign institutional investment strategy influences domestic institutional strategy or vice-versa.

\section{Keywords:}

Granger causality, Institutional investments, VAR

JEL Classification: F39, E44, C58 